\title{
Regulatory Assessment Date
}

National Cancer Institute

\section{Source}

National Cancer Institute. Regulatory Assessment Date. NCI Thesaurus. Code C94051.

The date (and time) on which this particular assessment is completed. 